\title{
REPRESENTASI KESENJANGAN SOSIAL-EKONOMI MASYARAKAT PESISIR DENGAN PERKOTAAN DALAM NOVEL GADIS PANTAI KARYA PRAMODYA ANANTA TOER
}

\author{
Nur Farida*, Eggy Fajar Andalas \\ Pendidikan Bahasa dan Sastra Indonesia, Universitas Muhammadiyah Malang, Indonesia \\ *Corresponding author: nurfarida1098@gmail.com
}

\section{INFORMASI ARTIKEL}

Sejarah Artikel

Diterima: 23/1/2019

Direvisi: $10 / 6 / 2019$

Disetujui: $12 / 10 / 2019$

Tersedia Daring: 30/6/2019

Kata Kunci:

Masyarakat Pesisir

Representasi

Kesenjangan

Ekonomi

Sosial-

(n)

Keywords:

Literary Work

Representation

Social-Economic Disparity

Penelitian ini bertujuan untuk mengetahui representasi kesenjangan sosial-ekonomi antara masyarakat pesisir dengan perkotaan dalam novel Gadis Pantai karya Pramoedya Ananta Toer. Representasi yang dimaksud merupakan cerminan atau gambaran dari kehidupan nyata masyarakat dalam karya sastra. Jenis penelitian ini adalah penelitian deskriptif-kualitatif dengan pendekatan sosiologi sastra. Sumber penelitian ini dari novel Gadis Pantai karya Pramoedya Ananta Toer. Data penelitian ini berupa kutipan, kalimat, dan paragraf yang menunjukkan kesenjangan sosial ekonomi antara masyarakat pesisir dengan perkotaan. Teknik pengumpulan data dilakukan dengan metode membaca dekat, mengidentifikasi data, dan memberi tanda. Teknik analisis data yang digunakan dalam penelitian ini adalah dengan rancangan analisis data yang di dipaparkan oleh Miles dan Huberman melalui langkah-langkah (1) penyeleksian data, (2) pemaparan data, dan (3) penarikan kesimpulan. Hasil penelitian ini memperlihatkan bentuk representasi kesenjangan sosial-ekonomi antara masyarakat pesisir dengan perkotaan dalam lima aspek seperti, aspek ekonomi, aspek pendidikan, aspek lingkungan, aspek sosial, dan aspek budaya. Berdasarkan dari lima aspek tersebut, ditemukan dikotomi bahwa masyarakat pesisir direpresentasikan sebagai masyarakat yang miskin, bodoh, kotor, terhina dan orang bawahan, sedangkan masyarakat perkotaan direpresentasikan sebagai bangsawan, pintar, kaya, terhormat, bersih, dan orang atasan. Hal tersebut terjadi karena pembangunan hanya berorientasi pada perkotaan sebagai pusat peradaban manusia di era kolonial.

\section{ABSTRACT}

This study aims to find out the representation of social-economic inequality between the coastal society and urban society in the novel Gadis Pantai by Pramoedya Ananta Toer. The representation is a reflection or image of the real life in the literary work. The study belongs to descriptive-qualitative research with sociology of literature approaches. The source of the study is the novel Gadis Pantai by Pramoedya Ananta Toer. The research data are in forms of quotes, sentences, and paragraphs which show the socialeconomic disparity between coastal communities and urban societies. The data collection techniques are carried out using the method of close reading, identifying, and sign giving. Meanwhile, the data analysis techniques employ Miles and Huberman's method through (1) data selection, (2) data exposure, and (3) decision making. The results of this study show a form of representation of social-economic inequalities between coastal communities and 
urban areas in five aspects, such as economic aspects, educational aspects, environmental aspects, social aspects, and cultural aspects. According to these five aspects, a dichotomy is found that coastal communities are represented as poor, dirty, disgraced, and subordinate people, while urban communities are represented as noble, smart, rich, respectful, clean, and superior individuals. This condition materializes as the development solely focuses on the urban area as the center of human civilization in the colonial era.

Copyright@2019, Nur Farida, Eggy Fajar Andala This is an open access article under the CC-BY-3.0 license
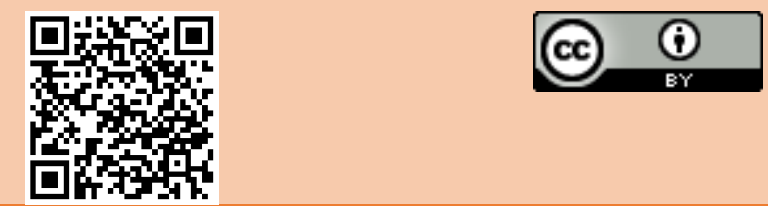

\section{PENDAHULUAN}

Kesenjangan merupakan salah satu keadaan atau kondisi yang tidak seimbang yang terdapat dalam kehidupan sosial-ekonomi masyarakat. Kesenjangan sosial-ekonomi sering kali terjadi di lingkungan masyarakat. Permasalahan kesenjangan utamanya sering terjadi pada ketidakmerataan pendapatan dan perbedaan pembangunan masyarakat perkotaan dan pesisir. Kesenjangan tersebut dipengaruhi salah satunya oleh realitas sosial-ekomomi yang terjadi (Meyrizki \& Pandjaitan, 2011). Kesenjangan merupakan salah satu tema yang sering digunakan dalam karya sastra. Karya sastra sering menangkap permasalahan-permasalahan sosialekonomi yang terjadi dalam masyarakat. Representasi merupakan gambaran atau cerminan kehidupan nyata suatu masyarakat dalam sebuah karya sastra, salah satunya adalah novel (Wanti, 2014). Novel dapat memuat berbagai persoalan dalam kehidupan manusia. Novel sering kali digunakan sebagai media kritik oleh pengarang, sehingga bentuk kepedulian pengarang terhadap kritik dalam sebuah karya sastra pada situasi kehidupan sosial atau masyarakat yang tidak sesuai dengan norma yang seharusnya. Berbagai aspek kehidupan manusia terekam secara baik dalam karya sastra, oleh karenanya karya sastra sering disebut sebagai dokumen sosio dalam masyarakat.

Penggambaran karya sastra yang banyak merekam berbagai representasi kehidupan masyarakat salah satunya adalah novel Gadis Pantai karya Pramoedya Ananta Toer. Hal ini dikarenakan novel-novel Pramoedya Ananta Toer memiliki kecenderungan mengangkat dikotomi antara masyarakat perkotaan dengan pesisir pada era kolonial. Novel Gadis Pantai termasuk novel roman yang mengisahkan kehidupan seorang anak gadis pantai yang dilahirkan di sebuah kampung nelayan di Jawa Tengah, Kabupaten Rembang, yang kemudian dalam karya sastra ini, gadis tersebut dinamai Gadis Pantai. Suatu hari pada awal abad 20-an ketika Gadis Pantai berusia empat belas tahun, gadis pantai dijodohkan oleh orang tuanya dengan seorang priyayi Karesidenan Rembang yang bekerja sebagai (administrasi) Belanda. Priyayi itu disebut sebagai Bendoro. Perkawinan itu memberikan derajat pada orang tua Gadis Pantai dan kampung halaman masyarakat pesisir, sehingga hidupnya lebih sejahtera. Kondisi demikian, menjadikan bangsawan atau priyayi yang menikahi seorang dari masyarakat kecil adalah hal yang luar biasa. Dengan adanya perkawinan itu status Gadis Pantai berubah, semula ia hanya gadis kampung yang miskin, tetapi sekarang menjadi istri Bendoro yang disebut sebagai Mas Nganten (Toer, 2006).

Melalui novel Gadis Pantai, pengarang mengambarkan mengenai kondisi masyarakat pesisir dengan perkotaan. Dalam novel digambarkan masyarakat pesisir hidup dalam 
keterbatasan sarana prasarana yang seadanya, sedangkan masyarakat perkotaan banyak digambarkan terdapat pembangunan-pembangunan yang sangat mendukung kehidupan masyarakat perkotaan. Dalam hal ini, masyarakat pesisir dengan perkotaan sangat jauh berbeda. Akibatnya terjadi kesenjangan yang sangat besar antara masyarakat pesisir dengan perkotaan pada masa kolonial.

Berdasarkan hal tersebut, peneliti ingin mengetahui bagaimana representasi kesenjangan sosial-ekonomi masyarakat pesisir dengan perkotaan dalam novel Gadis Pantai karya Pramoedya Ananta Toer. Akibatnya muncullah dikotomi antara masyarakat pesisir dengan perkotaan. Bentuk dikotomi tersebut seperti, kaya dan miskin, kota dan kampung, bangsawan dan nelayan, tinggal di gedung dan tinggal di gubuk, bersih dan kotor, orang atasan dan orang bawahan, makan nasi dan makan jagung, terhormat dan terhina. Representasi itu yang banyak digambarkan dalam novel Gadis Pantai karya Pramoedya Ananta Toer (Andalas, 2016).

Sepanjang penulusuran peneliti terhadap novel Gadis Pantai karya Pramoedya Ananta Toer, hanya menemukan lima penelitian yang telah melakukan kajian terhadap novel Gadis Pantai ini. Pertama dengan judul "Analisis Wacana Kritis Feodalisme dan Diskriminasi Perempuan Jawa dalam Novel Gadis Pantai Karya Pramoedya Ananta Toer" yang dilakukan oleh (Perwitasari \& Hendariningrum, 2014). Hasil penelitian menyimpulkan bahwa Pramoedya Ananta Toer cenderung mengeksplorasi ketidakadilan yang dialami oleh perempuan Jawa yang diwakili oleh Gadis Pantai untuk mengkritik praktik feodalisme di Jawa. Adanya ketidakadilan yang dialami oleh Gadis Pantai merupakan salah satu cara Pramoedya Ananta Toer yang sebenarnya ingin membangkitkan kesadaran pembaca dan empati terhadap apa yang terjadi pada Gadis Pantai. Selain itu, juga mengundang pembaca untuk melawan praktik-praktik ketidakadilan dalam semua aspek, terutama yang berhubungan dengan budaya Jawa yang masih menggunakan kelas-kelas sosial di masyarakat yang menempatkan perempuan sebagai makhluk sekunder setelah laki-laki. Penelitian kedua yang dilakukan oleh Nurhanifah (2012) dengan judul "Representasi Unsur Religi dalam Novel Gadis Pantai Karya Pramoedya Ananta Toer" menjelaskan bahwa representasi unsur religi di Jawa pada tahun 1950-an yang tergambar dalam novel Gadis Pantai terbagi ke dalam tiga bagian, yaitu abangan, santri, dan priyayi. Ketiga bagian tersebut merupakan salah satu komponen unsur religi, yaitu kelompok-kelompok religius atau kesatuan-kesatuan sosial yang menganut suatu sistem kepercayaan. Penelitian ketiga oleh Wibowo (2015) dengan judul "Novel Gadis Pantai Karya Pramoedya Ananta Toer sebagai Dasar Penciptaan Skenario" peneliti menyimpulkan bahwa kepiawaian Pramoedya Ananta Toer dalam menulis novel tidak diragunakan lagi, banyak karyanya yang menjadi best seller tetapi sampai saat ini belum ada yang berhasil difilmkan. Ide menjadi hal yang paling penting dalam sebuah skenario (film), ide mengadaptasi novel menjadi pilihan yang jitu. Penelitian keempat oleh Astuti (2016) dengan judul "Nilai sosial dalam Novel Gadis Pantai Karya Pramoedya Ananta Toer" menyimpulkan bahwa dalam penelitiannya mengandung nilai sosial yaitu, nilai material, nilai vital, dan nilai kerohanian. Niali-nilai tersebut sangat berkaitan dengan latar belakang cerita, Pramoedya Ananta Toer ingin memperjuangkan keselarasan kelas yang ada pada saat itu, dimana kaum atasan selalu menindas kaum bawahan bahkan cenderung menindas bangsa sendiri.

Berdasarkan kondisi tersebut, maka tujuan penelitian ini adalah untuk mengetahui representasi kesenjangan sosial-ekonomi masyarakat pesisir dengan perkotaan dalam novel Gadis Pantai karya Pramoedya Ananta Toer. Penelitian ini juga ingin mengetahui secara detail mengenai (1) perubahan perilaku masyarakat, dengan proses perubahan mulai dari masyarakat kelompok maupun masyarakat individu, (2) novel Gadis Pantai banyak merekam berbagai representasi kehidupan masyarakat pesisir dengan perkotaan pada masa kolonial, dan (3) penelitian ini dapat memberikan pengetahuan bahwa karya sastra dapat mengambarkan suatu 
persoalan atau kondisi masyarakat dalam novel tersebut. Oleh karena itu, hasil penelitian ini dapat digunakaan sebagai referensi atau pertimbangan untuk mengetahui representasi kesenjangan sosial-ekonomi masyarakat pesisir dengan perkotaan dalam novel Gadis Pantai karya Pramoedya Ananta Toer.

\section{METODE}

Penelitian ini merupakan jenis penelitian kualitatif dengan metode diskriptif. Penelitian ini termasuk dalam penelitian kualitatif karena bertujuan menggambarkan kehidupan masyarakat dengan cara deskriptif dalam bentuk kata-kata (Andalas, 2017). Metode deskriptif merupakan metode yang dilakukan dengan menganalisis data yang sudah dikumpulkan berupa kata-kata, gambar, dan bukan angka-angka (Moleong, 2013). Alasan penelitian menggunakan jenis penelitian diskriptif-kualitatif sesuai dengan pendapat Lofland, yang menyebutkan sumber data utama dalam penelitian kulitatif ialah kata-kata dan tindakan, selebihnya adalah tambahan seperti dokumen dan lain-lain (Moleong, 2013). Pendekatan yang digunakan dalam penelitian ini adalah sosiologi sastra, khususnya sosiologi karya sastra.

Sumber data penelitian ini adalah Novel Gadis Pantai Karya Pramoedya Ananta Toer yang diterbikan oleh Lentera Dipantara tahun 2006, yang terdiri dari 270 halaman. Data penelitiam ini berupa teks, kalimat, kata-kata, dan wacana yang memperlihatkan permasalahan mengenai representasi kesenjangan sosial-ekonomi masyarakat pesisir dengan perkotaan. Teks, kalimat, kata-kata, dan wacana tersebut berbentuk novel yang menunjukkan perilaku, pikiran, dan tindakan yang memperlihatkan permasalahan representasi kesenjangan sosiol-ekonomi masyarakat pesisir dengan perkotaan.

Teknik penggumpulan data dalam penelitian ini dilakukan dengan beberapa langkah yaitu: Pertama, membaca secara keseluruhan Kedua, mengidentifikasi. Ketiga, memberi tanda pada setiap data. Penelitian ini menggunakan instrumen panduan analisis data yang berupa tabel pengklasifikasian data. Instrumen ini digunakan untuk mengumpulkan data dari novel Gadis Pantai karya Pramoedya Ananta Toer dengan teknik baca dan catat. Teknik Analisis data yang digunakan merupakan model analisis Miles dan Huberman yang meliputi (1) penyeleksian data, (2) pemaparan data, dan (3) penarikan kesimpulan (Moleong, 2013).

\section{HASIL DAN PEMBAHASAN}

Hasil penelitian ini menunjukkan bahwa dalam novel Gadis Pantai, pengarang menggambarkan realitas sosial-ekonomi yang sering terjadi dalam kehidupan manusia. Dalam novel ini digambarkan kesenjangan sosial-ekonomi antara masyarakat pesisir dengan perkotaan. Akibatnya terjadi kesenjangan yang sangat besar dalam kehidupan antara masyarakat pesisir dengan perkotaan seperti; (1) aspek ekonomi, (2) aspek pendidikan, (3) aspek lingkungan, (4) aspek sosial, (5) aspek budaya. Representasi kesenjangan sosial-ekonomi antara masyarakat pesisir dengan perkotaan dapat dijelaskan sebagai berikut.

\section{Aspek Ekonomi}

Dalam novel ini, pengarang mengambarkan bahwa antara masyarakat pesisir dengan perkotaan memiliki kesenjangan yang sangat jauh berbeda dalam aspek ekonomi. Terutama pada kehidupan ekonomi masyarakat pesisir bergantung pada hasil-hasil lautan saja, sedangkan masyarakat perkotaan sektor ekonominya berpusat pada kegiatan di bidang distribusi. Hal tersebut, menjadikan kesenjangan ekonomi yang mencerminkan distribusi pendapatan yang tidak adil dan merata, karena pertumbuhan ekonomi yang tinggi hanya dinikmati oleh masyarakat perkotaan, sedangkan masyarakat pedesaan mendapat porsi yang kecil dan 
tertinggal (Syahza, Bakce, \& Hamlin, 2015). Representasi kesenjangan dalam aspek ekonomi dalam novel tergambarkan sebagai berikut.

"Ssst.. Jangan nangis. Mulai hari ini kau tinggal di gedung besar, nak. Tidak lagi di gubuk. Kau tak lagi menjahit layar dan jala, tapi sutera, nak. Stt, ssst. Jangan nangis." (Bab ke-1, Paragraf 9: hal 12)

Mereka mengikutinya berjalan di bawah jendela-jendela besar, melintasi perkarangan dalam yang ditumbuhi pohon-pohon delima serta pagar pohon kingkit. Mereka mendaki lantai, memasuki ruang belakang yang begitu besar, empat kali lebih besar dari seluruh rumah mereka. (Bab ke-1, Paragraf 23: hal 17)

Mereka sedang menghirup udara pagi di kebun belakang. Dan kebun belakang itu jauh lebih besar dari seluruh kampung nelayan tempat ia dilahirkan dan dibesarkan. Seluruhnya terpagari dinding tembok tinggi. (Bab ke-1, Paragraf 115: hal 40)

Data tersebut menunjukkan bahwa rumah di kota dan pesisir sangat berbeda. Rumah di kota sangat besar, empat kali dari rumah orang-orang kampung nelayan. Bahkan kebun belakang rumah orang kota jauh lebih besar dari seluruh kampung nelayan.

Hal tersebut, dikarenakan pembangunan di kawasan pesisir tidak terlepas dari daya dukung lingkungan. Bahkan rendahnya taraf kehidupan masyarakat pesisir dan akses yang terbatas akan aset dan sumber-sumber pembiayaan bagi kehidupan nelayan merupakan persoalan utama yang dijumpai di kawasan pesisir (Amanah, 2010). Terlihat kata gubuk dengan gedung tergambar sangat jauh berbeda. Di sana orang-orang kota tinggal di gedung, sedangkan orang-orang nelayan tinggal di gubuk. Artinya pembanguan selalu terpusat pada sudut-sudut perkotaan tertentu dan tidak secara merata. Jika dilihat dalam domestik yang lebih luas dibandingkan antara perkotaan dan pesisir kesenjangan lebih terlihat lagi. Pembangunan adalah salah satu representasi realitas di antara masyarakat pesisir dengan perkotaan.

"Apa yang kau makan di kampung sana?"

Tak mampu gadis pantai menjawab. Ia takut. Ia tak perna diajar menggunakan bahasa yang biasa dipergunakan di kota. Ia diam saja.

"Jagung?"

"Sahaya Bendoro."

"Jarang makan nasi?"

"Sahaya Bendoro."

"Bersyukurlah di sini kau selalu makan nasi. (Bab ke-1, Paragraf 117: hal 40)

Data di atas menggambarkan bahwa makanan pokok masyarakat pesisir adalah jagung. Berbeda dengan masyarakat perkotaan makanan pokoknya adalah nasi. Di kota kebutuhan pokok sangat melimpah dan terpenuhi. Hal tersebut terlihat pada kalimat "Bersyukurlah di sini kau selalu makan nasi”, dari kalimat itu Bendoro mengatakan kepada Gadis Pantai bahwa di kota tepatnya di rumah Bendoro akan selalu makan nasi. Berbeda di kampung nelayan makanan pokoknya selalu jagung.

Hal itu sesuai dengan pendapat (Ahmadi, 2010), dalam kehidupan ekonomi pada masyarakat pedesaan untuk memperoleh kebutuhan pokok mereka mengelolah alam untuk memperoleh bahan-bahan mentah, baik bahan kebutuhan pangan, sandang maupun lain-lain. Artinya, kehidupan masyarakat pesisir sangat minim untuk memenuhi kebutuhan pokok, karena masyarakat pesisir hanya bergantung pada sektor perikanan saja. Jadi, untuk memenuhi kebutuhan hidup setiap hari sangat sulit. Masyarakat pesisir harus bekerja keras untuk mendapatkan jagung sebagai kebutuhan pokok dalam kehidupan sehari-hari.

"Di mana sahaya mesti mandi Mas Nganten?" 


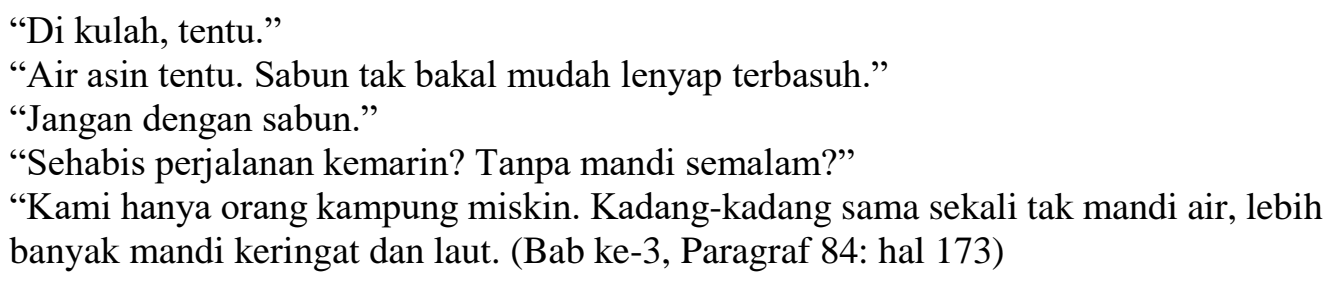

Berdasarkan data di atas, terdapat percakapan Mardinah dan Mas Nganten. Mardinah bertanya pada Mas Nganten tempat mandi di kampung nelayan. Dalam hal itu, Mas Nganten menjawab mandi "air asin tentu. Sabun tak bakal mudah lenyap terbasuh". Dari jawaban Mas Nganten, dapat di gambarkan bahwa masyarakat pesisir sangat miskin, terutama pada air bersih. Masyarakat pesisir lebih banyak mandi air keringat dan air laut daripada mandi air bersih. Terlihat dari data di atas bahwa masyarakat pesisir sangat kekurangan air bersih.

Air bersih merupakan air yang dapat dipakai sehari-hari untuk keperluan mencuci, mandi, memasak dan dapat diminum setelah memasak (Hakim, 2010). Air bersih dalam kehidupan manusia merupakan salah satu kebutuhan mendasar, sehingga perlu untuk dipenuhi dalam jumlah dan kualitas yang memadai. Pada masyarakat pesisir, air bersih sangat kurang, kebanyakan masyarakat pesisir menggunakan air laut untuk mandi, mencuci, dan kebutuhan lainnya. Jadi seharusnya pemerintah menyediakan air bersih untuk masyarakat pesisir, tidak hanya pada masyarakat perkotaan saja air bersih mudah didapatkan.

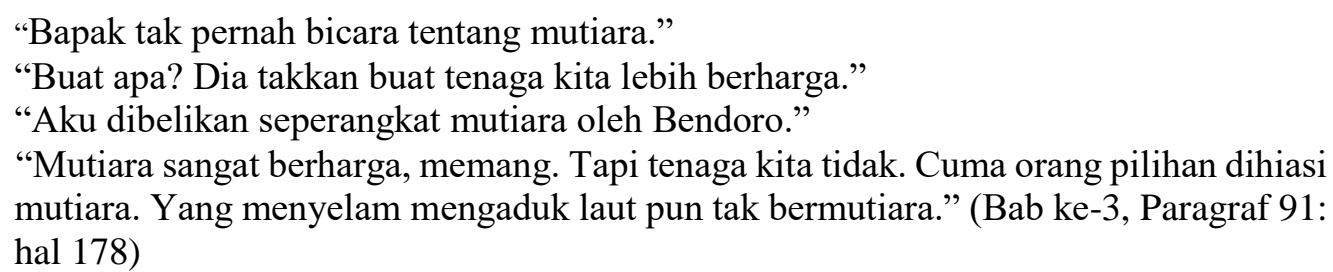

Dalam data tersebut, tergambarkan bahwa kehidupan ekonomi masyarakat perkotaan sangat terlihat mewah. Dari percakapan Emak dengan Gadis Pantai yang membicarakan tentang mutiara. Gadis Pantai bercerita kepada emak bahwa dia dibelikan seperangkat mutiara. Tetapi emak menasaheti Gadis Pantai bahwa mutiara sangat berharga dibandingkan tenaga para nelayan.

Hal tersebut, dapat dipahami dari kalimat "Cuma orang pilihan dihiasi mutiara, yang menyelam mengaduk laut pun tak bermutiara". Dari kalimat itu menyatakan bahwa orangorang yang memakai mutiara hanyalah orang kota atau orang-orang yang kaya. Masyarakat pesisir yang menyelam untuk mencari mutiara pun tidak memakai mutiara, karena masyarakat pesisir sangat membutuhkan uang bukan mutiara. Jadi masyarakat pesisir tidak memakai mutiara yang telah dicarinya. Hal itu, karena kehidupan perekonomian masyarakat pesisir hanya bergantung pada sektor perikanan saja. Menurut pendapat Syahwi (2011), potret kemiskinan itu terjadi sangat kontras karena sebagian masyarakat hidup dalam kelimpahan, sementara sebagian masyarakat hidup serba kekurangan. Artinya, bahwa masyarakat pesisir sangat miskin untuk mempertahankan hidup pun sangat sulit. Kekayaan bagi sejumlah orang berarti kemiskinan bagi orang lain.

\section{Aspek Pendidikan}

Pendidikan merupakan salah satu aspek pembangunan nasional dalam mencerdaskan kehidupan bangsa (Setiawan, 2015). Dalam novel Gadis Pantai terdapat perbedaan dalam aspek pendidikan yang menggambarkan secara nyata strata di masyarakat. Pada masyarakat kota, pendidikan adalah kewajiban untuk menempuh ilmu baik dalam pendidikan akademik 
maupun agama. Pendidikan yang tinggi sangat penting bagi masyarakat kota untuk mencapai tingkat pertumbuhan ekonomi yang baik. Berbeda pada masyarakat pesisir, yang mengaggap pendidikan tidak begitu penting, mereka lebih mementingkan bekerja untuk mencukupi kehidupannya karena pada era kolonial pembangunan pendidikan kurang memadahi. Hal tersebut, menyebabkan rendahnya daya saing dalam memperebutkan peluang pekerjaan yang lebih layak secara ekonomi. Selain itu, tingkat pendapatan yang rendah menyebabkan kemiskinan yang seolah telah menjadi teman akrab. Kutipan data yang membahas mengenai aspek pendidikan dapat dilihat pada data berikut.

Seperempat jam kemudian terdengar suara Bendoro Guru Bicara dalam bahasa yang mereka tak kenal dan suara Agus Rahmat menjawab dalam bahasa yang mereka pun tidak kenal. "Betapa hebat Bendoro mengajar putera-putranya," kepala kampung berbisik. "Sekecil itu sudah bisa berbicara bahasa Belanda. Satu kata pun kita tidak paham. Anakmu nanti," kepala kampung menghadapkan mukanya kepada Gadis Pantai," juga bakal diajar seperti itu." (Bab ke-1, Paragraf 34: hal 21)

Data di atas memperkuat bukti bahwa masyarakat perkotaan, terutama dalam golongan tokoh Bendoro, berbicara dalam bahasa Belanda dengan Agus Ramhad (anak laki-laki). Bahasa Belanda digunakan sebagai bahasa sehari-hari pada lingkungan Bendoro, khususnya pada anakanaknya. Terlihat pada kalimat "Sekecil itu sudah bisa berbicara bahasa belanda". Dari kalimat itu, dapat diketahui bahwa dalam kehidupan sehari-hari masyarakat perkotaan menggunkan berbagai bahasa, terutama bahasa Belanda. Anak-anaknya sudah diajarkan bahasa Belanda mulai sejak kecil.

Dalam pandangan (Setiawan, 2015), pendidikan merupakan salah satu fungsi yang harus dapat dilakukan sebaik-baiknya oleh keluarga maupun masyarakat secara terpadu dengan berbagai lembaga yang memang diadakan secara sengaja untuk mengemban fungsi pendidikan. Dari situlah Bendoro sangat mementingkan pendidikan pada anak-anaknya, karena pendidikan menjadi kebutuhan dasar manusia. Bahkan pendidikan banyak memberi pengetahuan tentang berbagai hal, bahkan memegang peran yang sangat penting dalam pembangunan sosial, dan pertumbuhan ekonomi. Terlihat jelas, bahwa masyarakat perkotaan sangat mementingkan pendidikan bagi anak-anaknya.

Betapa halus tangan itu: tangan seorang ahli-buku! Hanya buku yang dipegangnya, dan bila bambu tipis panjang penunjuk baris. Tidak seperti tangan bapak dan emak, yang selalu nelayan ke udara dan mendarat di salah satu bagian tubuhnya pada setiap kekeliruan yang dilakukannya. Dan tangan yang kasar itu segera meninggalkan kesakitan pada tempat-tempat tertentu pada tubuhnya, tapi hatinya tak perna terjamah, apa lagi terusik. (Bab ke-1, Paragraf 90: hal 33)

Berdasarkan data di atas dapat menegaskan bahwa orang perkotaan rata-rata mempunyai tangan halus karena tidak bekerja dengan keras, hanya memegang buku saja. Berbeda dengan orang-orang nelayan, yang pekerjaannya setiap hari memegang bambu, pasti mempunyai tangan yang kasar. Dari novel Gadis Pantai digambarkan bahwa orang tua Gadis Pantai yang tinggal di kampung nelayan, telah bekerja keras sehingga tangannya kasar. Terlihat dari kalimat "Tidak seperti tangan bapak dan emak, yang selalu nelayan ke udara. Dan tangan yang kasar itu”.

Menurut Rahman (2012) bahwa dalam kehidupan sehari-hari masyarakat pesisir sibuk bekerja untuk mencukupi kehidupannya, terutama pada anak-anak usia sekolah, mereka semua bekerja untuk membatu orang tua, mulai dari mempersiapkan keperluan untuk pergi ke laut sampai menjual hasil tangkapan. Artinya, bahwa masyarakat pesisir selalu bekerja keras untuk 
memenuhi kehidupannya. Akibatnya rata-rata tingkat pendidikan masyarakat pesisir rendah, sehingga sektor ekonominya hanya bargantung pada hasil laut. Berbeda dengan masyarakat perkotaan yang selalu memegang buku, itu disebabkan karena tingkat pendidikan di sana sangat tinggi sehingga peluang pekerjaan sangat mudah untuk didapatkan. Dari situlah sangat jelas kesenjangan pendidikan antara masyarakat pesisir dengan perkotaan.

Dari dalam kutangya Mardinah mengeluarkan sepucuk surat bersampul. Ragu-ragu sambil menatap mardinah Gadis Pantai menerimanya. Waktu itu emak, saudarasaudara, dan bapak masih tinggal di rumah. Mereka semua berdiri tanpa menyilakan duduk tamu-tamu tak di undang itu. "Mas Nganten tak bisa baca. Mari sahaya bacakan." "Siapa di kampung ini yang bisa baca, bapak?" "Siapa? Tak ada." (Bab ke3, Paragraf 166: hal 204)

Data tersebut membuktikan bahwa masyarakat pesisir tidak bisa membaca. Kalimat "Siapa di kampung ini yang bisa baca, bapak? Siapa? Tak ada" dalam kalimat itu sangat jelas bahwa masyarakat pesisir kurang mengenyam pendidikan. Berbeda dengan masyarakat perkotaan yang sudah bisa membaca, terlihat dalam kalimat "Mas Nganten tak bisa baca. Mari sahaya bacakan”. Dari kalimat itu Mardinah (orang kota) menawarkan diri pada Mas Nganten untuk membacakan suratnya. Hariyanto (2014) mengungkapkan bahwa pembangunan yang dilakukan lebih fokus pada wilayah perkotaan, sehingga pemerataan yang diinginkan belum sepenuhnya dapat dinikmati oleh masyarakat pesisir. Maka terlihat bahwa rata-rata masyarakat perkotaan dalam pembangunan sudah sangat maju dan dapat digunakan untuk meningkatkan kesejahteraan. Berbeda dengan masyarakat pesisir yang terdapat hambatan dalam pembangunan pendidikan, sehingga pembangunan untuk pendidikan masih belum ada.

Di kampung nelayan pembagunan pendidikan tidak mewadahi, sehingga mengakibatkan masyarakat pesisir menjadi bodoh dan tidak bisa membaca. Hal tersebut, karena kurangnya perhatian pemerintah dalam pemerataan pembangunan pendidikan, sehingga masyarakat pesisir tidak memiliki perencanaan yang matang untuk pendidikan anak-anaknya. Biasanya masyarakat pesisir telah membiasakan anak-anaknya untuk bekerja sejak usia dini. Pendidikan bagi mereka adalah kebutuhan nomer sekian, kebutuhan yang utama adalah mencukupi kehidupan dalam sehari-hari.

\section{Aspek Lingkungan}

Lingkungan hidup tidak dapat dipisahkan dari ekosistem yang merupakan satuan kehidupan yang terdiri atas suatu komunikasi makhluk hidup, baik itu benda mati yang membentuk suatu sistem (Rusdina, 2015). Lingkungan menjadi tempat tinggal yang akan mempengaruhi keadaan dan juga kehidupan manusia setiap hari. Maka dari itulah, keadaan lingkungan memegang peran yang sangat penting dalam kehidupan masyarakat pesisir dengan perkotaan. Lingkungan yang bersih pastinya akan memberi dampak kehidupan yang sehat, seperti kehidupan masyarakat di perkotaan. Sebaliknya, lingkungan yang tercemar pasti akan menyebabkan dampak buruk pada masyarakat pesisir, kondisi demikian tergambar dalam dialog tokoh sebagai berikut.

Sepuluh tahun yang baru lalu aku juga perna datang ke kampungmu. Kotor, miskin, orangnya tidak perna beribadah. Kotor itu tercela, tidak dibenarkan oleh orang yang tau agama. Di mana banyak terdapat kotoran, orang-orang disitu kena murka Tuhan, rezeki mereka tidak lancar, mereka miskin. (Bab ke-1, Paragraf 118: hal 41)

Aku masih ingat pada hari-hari pertama. Bendoro bilang kami orang-orang jorok, tak tahu iman, itu miskin kau mengerti agama?" (Bab ke-3, Paragraf 39: hal 159) 
Kotor! Tiba-tiba ia ingat pada hukuman Bendoro pada orang-orang kampung nelayan ini. Mereka kotor kurang beriman, karena itu miskin kata Bendoro. Kalau semua mau serba bersih terus siapa yang lenyapkan kotoran? Ia bertanya lugu pada Bendoro. (Bab ke-3, Paragraf 102: hal 183)

Data tersebut menunjukkan bahwa di kampung nelayan sungguh berbeda dengan perkotaan. Tokoh Bendoro mengambarkan kampung nelayan terdapat laut, anekah macam ikan dan terasi udang yang sangat terasa bau. Bahkan Bendoro berkata "di mana banyak terdapat kotoran, orang-orang disitu kena murka Tuhan, rezeki mereka tidak lancar”. Kalimat itu menunjukan bahwa kebersihan itu sebagian dari iman. Maka sebagai masyarakat yang beragama Islam harus menjaga kebersihan, agar rezeki masyarakat pesisir lacar. Adanya lingkungan yang bersih akan membuat masyarakat pesisir hidup dengan nyaman.

Hal tersebut seharusnya menjadikan dasar perilaku masyarakat untuk meningkatkan kesadaran terhadap lingkungan dengan melestarikan hal-hal yang ada di sekitarnya, salah satunya dengan tidak merusak lingkungan alam (Tamara, 2016). Kondisi tersebut menjadi salah satu yang mengakibatkan keadaan lingkungan masyarakat pesisir memburuk setiap harinya. Kehidupan masyarakat pesisir sangat tergantung pada kondisi lingkungan, serta sangat rentan pada kerusakan lingkungan, khususnya pada pencemaran. Akibatnya kampung nelayan menjadi kotor dan jorok. Oleh karena itu, lingkungan sangat penting untuk dijaga dan dilestarikan agar tidak berdampak negatif pada kehidupan sehari-sehari. Lingkungan yang bersih menyebabkan kehidupan yang layak untuk di tempati.

\section{Aspek Sosial}

Aspek sosial merupakan hubungan timbal balik antara manusia dan lingkungan. Kondisi lingkungan menentukan perilaku manusia, dimana lingkungan akan menentukan bagaimana seseorang merespon kondisi yang dihadapi (Pinto, 2015). Setiap manusia memiliki perilaku yang berbeda-beda dalam menjalin interaksi dengan lingkungannya. Terutama pada masyarakat pesisir dengan perkotaan memiliki perilaku yang berbeda dalam kehidupan sosial. Perbedaan ini dapat diwujudkan dalam kenyataan-kenyataan sosial yang menjadi titik perhatiannya sebagai berikut.

\footnotetext{
"Ambilah ini buat mak."

"Aku dan bapakmu banting tulang biar kau rasakan pakai kain, pakai kebaya, kalung, anting seindah itu. Dan gelang ular itu...,"sekarang emaknya terhenti bicara, menahan sedan.

Kemudian meneruskan, "Uh-uh-uh, tak perna aku mimpi anakku perna mengenakannya," Dan sekarang meledak tangisan yang tertahan (Bab ke-1, Paragraf 13: hal 13)
}

Data tersebut menunjukkan bahwa dalam novel Gadis Pantai, orang tua Gadis Pantai bekerja banting tulang untuk anaknya. Agar menjadi istri pembesar yang bisa mengangkat derajat dan kehormatan bagi orang tua maupun masyarakat kampung nelayan. Pandangan masyarakat di kampung nelayan menempatkan seorang pembesar selalu direpresentasikan dengan emas. Kedudukan emas bagi masyarakat di kampung nelayan memiliki nilai material yang tinggi dan sangat bermanfaat.

Sebagaimana dikemukakan oleh Daraba (2015) bahwa kemiskinan dilukiskan sebagai kurangnya pendapatan untuk memenuhi kehidupan pokok. Dikatakan berada pada garis kemiskinan apabila pendapatan tidak cukup untuk memenuhi kebutuhan hidup yang paling pokok seperti pangan, pakaian, dan tempat berteduh. Memakai perhiasan emas dapat juga 
menaikkan status pemakainya, dengan menggunkan perhiasan seperti kalung, gelang, cincin, dan giwang akan terlihat seperti orang kaya. Namun, bagi masyarakat pesisir jarang ada yang menggunakan emas karena seorang nelayan penghasilannya hanya untuk mencukupi kehidupan sehari-hari.

"Dia pembesar, nak, orang berkuasa sering di panggil Bendoro Bupati. Tuan besar residen juga pernah datang ke rumahnya, nak. Semua orang tahu.” (Bab ke-1, Paragraf 15: hal 14)

Data tersebut menunjukkan bahwa rata-rata masyarakat perkotaan dalam novel Gadis Pantai digambarkan sebagai Bendoro atau Pembesar. Dapat di lihat pada kalimat "orang berkuasa sering di panggil Bendoro Bupati", dari kalimat itu sudah jelas bahwa masyarakat perkotaan sangat berkuasa karena mereka berkehidupan mewah dan mempunyai segalanya tanpa meminta bantuan orang lain.

Hal itu sesuai dengan pendapat Rosana (2011) bahwa antara masyarakat pedesaan dan perkotaan pada umumnya memiliki perbedaan mengenai nilai sosial, norma sosial, pola perilaku organisasi, susunan lembaga kemasyarakatan, lapisan-lapisan dalam masyarakat, kekuasaan dan wewenang, interaksi sosial, dan lain sebagainya. Bagi masyarakat pesisir, kota adalah pusat kekuasaan, kekayaan, dan sekaligus pengetahuan. Artinya, orang-orang berkuasa hanyalah orang yang kaya dan berpendidikan tinggi, seperti masyarakat kota. Masyarakat pesisir tidak dapat berkuasa, karena mereka bodoh dan miskin, sehingga di sana yang berkuasa hanyalah laut, karena laut sebagai sektor utama untuk pendapatkan kebutuhan hidup bagi masyarakat pesisir.

"Jadi dengan siapa Bendoro sehari-hari di sini?"

"Seorang diri. Tamu-tamu diterima di ruang tengah. Di sini tidak menerima tamu wanita."

"Megapa tidak? Di kampung kami pria dan wanita sama-sama bertamu. (Bab ke-2,

Paragraf 13: hal 80)

Data di atas menunjukan bahwa masyarakat perkotaan yang digambarkan sebagai orangorang bangsawan atau priyayi khususnya pada novel Gadis Pantai, dalam interaksi antara masyarakat tidak menerima tamu wanita. Berbeda dengan masyarakat pesisir yang interaksi antar masyarakat terlihat pada kalimat "Di kampung kami pria dan wanita sama-sama bertamu”. Dari kalimat itu masyarakat pesisir sangat mudah untuk berinteraksi dengan masyarakat lain. Wanita dengan laki-laki diperbolehkan sama-sama bertamu ke rumah masingmasing, tidak ada halangan di kampung pesisir untuk menerima tamu.

Menurut Ahmadi (2010) mereka mempunyai pergaulan hidup yang saling kenal mengenal, ada pertalian perasaan yang sama tentang kesukaan terhadap kebiasaan, bekerja sama untuk mencapai kepentingan-kepentingan mereka. Hal itu, dikarenakan mereka beranggapan sama-sama sebagai anggota masyarakat yang saling mencintai saling menghormati, mempunyai tanggungjawab yang sama terhadap keselamatan dan kebahagian bersama di dalam masyarakat. Bahkan kehidupan masyarakat pesisir dalam satu wilayah mereka saling rukun, karena prinsip masyarakat pesisir kerukunan yang menjiwai hubungan sosial masyarakat. Sebaliknya pada masyarakat perkotaan, dalam berinteraksi lebih di pengaruhi oleh pola ekonomi daripada pola sosial. Hal tersebut, karena status sosial sangat memegang peran penting bagi masyarakat pesisir. Jadi dalam kehidupan masyarakat pesisir sangat mudah berinteraksi dengan siapa pun. 
Betapa mahalnya pengetahuan di sini. Aku harus belajar segala, dari membatik, menyulam sampai membaca dan mengaji. Terkecuali belajar tentang suami sendiri, bahkan juga pendapat suami tentang istrinya. Di kampung ia sering dengar istri-istri pada mengkritik suami masing-masing. Kadang-kadang kritik itu membuat mereka pada bertengkar, tapi disini? Di sini? "Mbok perna tinggal di kampung nelayan? "Pernah, Mas Nganten." "Suami istri hidupnya tidak seperti disini." (Bab ke-2, Paragraf 27: hal 87)

Berdasarkan data di atas, Gadis Pantai berpikir bahwa betapa mahalnya pengetahuan di masyarakat perkotaan. Dia harus belajar banyak hal seperti membatik, menyulam, membaca, dan mengaji. Terkecuali belajar tentang suaminya sendiri yaitu kepada Bendoro. Di kampung Gadis Pantai sering mendengar bahwa dalam kehidupan berumah tangga baik suami maupun istri saling mengkritik, tetapi di kota kehidupan suami istri tidak seperti di kampung nelayan.

Keluarga mempunyai interaksi dan hubungan yang memberikan ikatan yang jauh lebih lama. Interaksi pasangan suami istri dapat dikonsepkan ke dalam tiga komponen dasar yaitu (1) kesesuaian dalam persepsi peran, (2) timbal balik peran, dan (3) kesetaraan fungsi peran. Maksudnya, tiga komponen tersebut adalah mengemukakan apa yang dirasakan oleh suami maupun istri. Dalam novel Gadis Pantai digambarkan bahwa dalam kehidupan masyarakat kota terutama pada orang bangsawan atau priyayi, suami yang terlalu berkuasa. Di kota ingin bertemu dengan suami saja sangat sulit jika tidak dikehendaki karena para suami sibuk dengan pekerjaannya, apalagi untuk mengkritiknya. Istri tidak berhak mempunyai keinginan, keinginan itu hanya ada pada suami, sedangkan istri hanya menunggu.

\section{Aspek Budaya}

Indonesia merupakan bangsa besar, secara geografi wilayahnya terdiri banyak pulau yang dihuni oleh beraneka etnis, budaya, agama, bahasa daerah hingga warna kulit. Kebudayaan merupakan warisan dari nenek moyang bagi masyarakat yang bersangkutan, karena budaya akan mewarisi setiap generasi suatu bangsa. Yunus (2013) menjelaskan bahwa budaya memiliki nilai-nilai yang senantiasa diwariskan, ditafsirkan, dan dilaksanakan seiring dengan proses perubahan sosial kemasyarakatan, sehingga selalu ada nilai-nilai budaya masyarakat yang masih tetap lekat pada masyarakat. Terutama pada masyarakat pesisir dengan perkotaan banyak perbedaan-perbedaan budaya sebagaimana kutipan berikut.

Ia sendiri pun tidak perna takut pada laut. Mengapa takut pada Bendoro? Mengapa? Bapak lebih kukuh dan kuat dari Bendoro. Bendoro bertubuh tinggi langsing, berwajah pucat, kulitnya terlalu halus, ototnya tak berkembang. Mengapa semua orang takut? Juga diriku. (Bab ke-1, Paragraf 142: hal 48)

Berdasarkan data di atas menggambarkan bahwa seorang Bendoro atau Priyayi yang identik dengan kota sangat ditakuti oleh masyarakat kecil. Paparan data tersebut menunjukkan bahwa Gadis Pantai merenungkan dirinya sendiri yang tidak pernah takut pada laut, mengapa dia harus takut pada Bendoro. Bukan Gadis Pantai saja yang takut pada Bendoro, tetapi semua orang juga takut. Terutama pada orang-orang yang tidak sederajat.

Kesenjangan dipandang sebagai masalah karena bertentangan dengan cita-cita masyarakat, yaitu terwujudnya suatu masyarakat yang adil dan sejahtera. Kesenjangan masyarakat pesisir dengan perkotaan dianggap sebagai sumber masalah dari segi sosial, ekonomi, budaya, dan politik. Artinya, orang yang kaya dan memiliki segalanya seperti Bendoro atau Priyayi sangat ditakuti oleh masyarakat kecil. Hal ini disebabkan mereka bisa melakukan apapun yang mereka inginkan. Meskipun Bendoro mempunyai badan yang tinggi langsing, berwajah pucat, dan tidak berotot, tapi mereka memiliki derajat yang tinggi. Berbeda 
dengan masyarakat pesisir yang gagah, kuat, dan berani pada laut tapi mereka takut pada Bendoro karena derajat mereka ada di bawah orang kaya.

"Ah, hanya orang kebanyakan dikawini dengan keris,"tida-tiba bujang itu terkejut sendiri. "Tidak kalau pengantin pria berhalangan, juga diwakilkan dengan keris." "Mengapa orang mesti kawin Mbok?" Bujang itu tertawa, dan kepalanya digelenggelengkan. "Ah, Mas Nganten ini. Bagi orang kebanyakan seperti sahaya ini kita kawin supaya semakin susah. Tentu beda dengan priyayi besar, mereka kawin supaya jadi senang.” (Bab ke-1, Paragraf 165: hal 56)

Pada data di atas, Gadis Pantai dikawinkan dengan seorang Bendoro yang digambarkan sebagai Priyayi atau Bangsawan. Gadis Pantai bertanya pada si mbok, mengapa orang harus kawin. Mbok menjawab, bahwa orang kebanyakan kawin supaya susah. Berbeda dengan orangorang besar seperti Bendoro, mereka kawin supaya jadi senang. Dalam kehidupan seorang Bendoro atau Bangsawan, budaya yang digunakan dalam pernikahan adalah keris. Keris digunakan sebagai perwakilan pria, jika pria berhalangan hadir. Para Bangsawan yang menikahi masyarakat kecil sering diwakilkan menggunakan keris, karena masyarakat kecil dinikahi hanya sebagai istri pencobaan seperti yang dialami oleh Gadis Pantai.

Menikah merupakan hal yang lazim bagi manusia dengan tujuan untuk membentuk keluarga yang bahagia, sejahtera dan kekal selamanya. Tetapi bagi masyarakat kecil, seperti masyarakat pesisir menikah membuat mereka semakin susah karena faktor ekonomi. Keadaan hidup yang berada dalam garis kemiskinan menjadi alasan utama dibaalik itu semua. Berbeda dengan masyarakat kota yang seperti Bendoro, menikah merupakan kesenangan, seperti mempunyai istri pencobaan dengan menikahi orang-orang yang tidak sederajat.

"Biarkan emak kawani aku disini, kalau aku tak boleh tidur di kamar dapur." "Itu tidak layak bagi wanita utama." "Dia emakku, emakku sendiri, Mbok." "Begitulah Mas Nganten, biar emak sendiri, kalau emaknya orang kebanyakan, dia tetap seorang sahanyanya." "Tidak, tidak, akulah sahaya emakku. Di kampungku aku lakukan segalah perintahnya, aku akan terus lakukan perintahnya." "Itulah salahnya Mas Nganten, adat priyayi tinggi lain lagi. Dan ini kota bukan kampung di tepi pantai." (Bab ke-1, Paragraf 169: hal 58)

“Ah, Mas Nganten, di kota, barangkali di semua kota-dunia kepunyaan lelaki. Barang kali di kampung nelayan tidak. Di kota perempuan berada dalam dunia yang di punyai lelaki, Mas Nganten.” (Bab ke-2, Paragraf 27: hal 87)

Dalam data di atas diceritakan bahwa Gadis Pantai meminta pada Embok agar Emaknya tidur bersama Gadis Pantai, tetapi Embok melarang Gadis Pantai tidur dengan Emaknya. Seorang wanita utama tidak pantas tidur dengan seorang sahaya yaitu seorang bawahan seperti Emak Gadis Pantai. Gadis pantai membantah bahwa di kampung nelayanan sana, seorang yang harus dihormati adalah Emaknya. Berbeda dengan adat priyayi yang harus dihormati adalah seorang Bendoro atau suaminya yang berkuasa dalam rumah tangganya.

Menurut Aryadi (2012) bahwa perubahan sosial lekat dengan perubahan budaya. Perubahan-perubahan budaya menekankan pada perubahan sistem nilai, sedangkan perubahan sosial pada sistem pelembangaan yang mengatur tingkah laku anggota masyarakat. Hal itu, disebabkan karena sebagian besar golongan priyayi hidup mewah di kota, sehingga orang kota seperti Bendoro sangat berkuasa. Oleh karena itu, adat-adat seorang Bendoro harus patuh padanya, yang berkuasa hanyalah Bendoro tidak ada lagi. Sebaliknya, berbeda di kampung nelayan yang harus dihormati dan dipatuhi perintahnya hanyalah orang yang tertua. 
Sementara itu dalam kepala Gadis Pantai mengaum-ngaum cerita-cerita pelayan tua itu, cerita tentang segala-galanya, tentang nasib orang bahawan dan kebesaran orang atasan, tentang kejatuhan orang bawahan yang menumpang diri pada orang atasan, tentang kekuasaan dan tentang takdir, tentang Gusti Allah dan tentang kompeni (Bab ke-2, Paragraf 63: hal 105).

Berdasarkan data tersebut, Gadis Pantai bercerita kepada pelayan tua (Embok) tentang nasib orang bawahan dan orang atasan. Kondisi ini sejalan dengan kehidupan Gadis Pantai yang dikawinkan dengan seorang Bendoro agar orang tuanya menjadi terhormat dan terpandang di kampunya. Sebaliknya, pada orang atasan (masyarakat kota) mereka selalu berkuasa dan tidak pernah memerlukan orang kecil seperti masyarakat pesisir.

Dalam hal tersebut, terjadi perbedaan kehidupan masyarakat pesisir dengan perkotaan. Berkaitan dengan hal itu, Syahwi (2011) memaparkan bahwa perbedaan-perbedaan itu berasal dari ketimpangan antar sektor ekonomi akibat kegagalan strategi pembangunan yang mengakibatkan adanya dampak terhadap personalitas dan segi-segi kehidupan. Perbedaan itu terjadi pada masyarakat pesisir dengan perkotaan. Masyarakat pesisir dalam kehidupannya menderita dari faktor ekonomi, sedangkan masyarakat kota berkuasa atas kekayaannya. Bahwa rata-rata orang bawahan seperti masyarakat pesisir selalu membutuhkan orang lain. Berbeda dengan orang atas seperti masyarkat kota yang selalu berkuasa dan tidak membutuhkan orang lain (individu) karena mereka memiliki segalanya.

\section{PEMBAHASAN}

Pada pembahasan ini diuraikan mengenai representasi kesenjangan sosial-ekonomi antara masyarakat pesisir dengan perkotaan. Selain itu, pembahasan ini dikaitakan dan dibandinkan dengan penelitian yang relevan. Representasi itu, ditemukan dalam lima wujud realitas kehidupan antara masyarakat pesisir dengan perkotaan dalam novel Gadis Pantai karya Pramoedya Ananta Toer. Pertama, aspek ekonomi, kedua, aspek pendidikan, ketiga, aspek lingkungan, keempat, aspek sosial, dan kelima, aspek budaya. Representasi kesenjangan sosialekonomi antara masyarakat pesisir dengan perkotaan dapat dijelaskan sebagai berikut.

\section{Aspek Ekonomi}

Dalam novel Gadis Pantai, kehidupan masyarakat pesisir dan perkotaan memiliki kesenjangan yang berbeda dalam aspek ekonomi. Kesenjangan ekonomi yang terjadi pada masyarakat pesisir sangat rendah dibandingkan masyarakat kota. Masyarakat pesisir dalam pembangunan hingga kebutuhan sandang pangan sangat minim untuk didapatkan di kampung. Hal tersebut, terjadi karena tidak meratanya pembangunan dan lapangan pekerjaan pada masyarakat pesisir, sehingga untuk memehuni kebutuhan hidup sehari-hari sangat sulit didapatkan. Berbeda dengan masyarakat kota yang sanagt mudah untuk mendapatkan kebutuhan sandang pangan. Hal itu terjadi karena akses pembangunan pada masyarakat kota sudah memenuhi taraf kehidupan yang baik, sehingga untuk mencari lapangan pekerjaan sangat banyak, jadi masyarakat kota mudah untuk memenuhi kehidupannya.

Temuan yang ditemukan oleh peneliti ini berbeda dengan penelitian sebelumnya mengenai kesenjangan sosial-ekonomi yang dilakukan oleh Juhari, terutama dalam aspek ekonomi. Hal itu, karena penelitian yang dilakukan oleh Juhari lebih menekankan pada ajaran agama Islam. Menurut Juhari (2010) peranan zakat itu terletak pada bagaimana seorang penerima maupun seorang yang menghidupi dirinya sendiri dengan kemampuan yang dimilikinya dan memiliki penghasilan tetap yang mencukupi kehidupannya sehingga ia tidak perlu bergantung kepada bantuan orang lain. Artinya, bahwa peranan zakat belum berfungsi sebagai instrumen pemerataan ekonomi bagi masyarakat yang membutuhkan, karena rata-rata 
masyarakat hanya menunggu zakat dari orang lain. Masyarakat tidak mencari kebutuhan hidupnya dengan bekerja keras untuk memenuhi kelayakan hidupnya sendiri. oleh karena itu, terlihat bahwa terjadi ketidakseimbangan ekonomi bagi masyarakat karena masyarakat tersebut tidak berusaha memperbaiki ekonominya dengan bekerja keras, mereka hanya menunggu zakat dari orang lain. Perbedaan dengan penelitian ini, terjadi kesenjangan ekonomi karena sektor pekerjaan masyarakat pesisir hanya pada lautan atau nelayan saja. Hal itu terjadi karena tidak meratanya pembangunan di pesisir, sehingga masyarakat pesisir sulit untuk mencari lapangan pekerjaan. Hal ini sehingga menyebabkan ketidaksetaraan dengan masyarakat kota yang lapangan pekerjaan mudah untuk didapatkan.

\section{Aspek Pendidikan}

Pada aspek pendidikan sangat terlihat jelas bahwa terdapat kesenjangan pada masyarakat pesisir. Kesenjangan itu, terlihat dari tidak meratanya pembangunan pendidikan yang mewadahi pada masyarakat pesisir. Hal itu menyebabkan masyarakat pesisir bodoh dan tidak bisa membaca, kondisi tersebut karena tidak ada sarana prasarana pendidikan. Latar belakang tersebut yang menyebabkan ekonomi masyarakat pesisir sangat rendah. Semua itu terjadi pada zaman kolonial karena pemerintah hanya mempioritaskan pendidikan di kota besar saja. Berbeda dengan masyarakat kota yang sudah mengenyam pendidikan mulai sejak dini, sehingga mempunyai banyak ilmu untuk mencari lapangan pekerjaan sangat mudah, akhirnya berdampak pada ekonomi yang stabil.

Karya sastra merupakan sebuah realitas yang banyak menggambarkan kondisi dalam kehidupan manusia. Pada penelitian sebelumnya yang dilakukan oleh Hidayat mengenai kesenjangan sosial-ekonomi, terutama dari aspek pendidikan memiliki keterkaitan erat. Berdasarkan pendapat Hidayat (2018) bahwa penyebab terjadinya kesenjangan dalam bidang pendidikan yaitu; (1) rendahnya sarana sekolah sebagai salah satu penunjang kebutuhan keberlangsungan terjadinya pendidikan, (2) redahnya kualitas guru atau pengajar sebagai pedoman untuk mendapatkan ilmu pengetahuan secara baik, (3) faktor infrastruktur yang mempengaruhi keberhasilan penyelenggaraan pendidikan, dan (4) mahalnya biaya pendidikan yang menjadi acuan dalam mendapatkan pendidikan dengan kualitas masing-masing.

Hal itu, sama seperti dalam ranah sastra yang terdapat pada novel Gadis Pantai. Bahwa penyebab kesenjangan pendidikan yang terjadi pada masyarakat pesisir adalah ketidakmerataan pembangunan yang menunjang pendidikan, sehingga masyarakat pesisir tidak dapat mengenyam pendidikan. Pemerataan pembangunan pendidikan hanya terdapat pada masyarakat kota. Kondisi tersebut terjadi karena kurangnya perhatian pemerintah dalam penyediaan sarana dan prasarana pendidikan yang didistribusikan hingga wilayah-wilayah terpencil, terluar, dan terpelosok seperti pada kampung pesisir. Jika dibandingkan dengan daerah-daerah yang aksesibilitasnya mudah terjangkau seperti pada perkotaan, maka pembangunan pendidikan berkembang dengan baik. Hal itulah yang menjadi kesenjangan sosial-ekonomi antara masyarakat pesisir dengan perkotaan.

\section{Aspek Lingkungan}

Dari aspek lingkungan masyarakat pesisir dan kota memiliki ketidaksetaraan. Hal itu terjadi karena masyarakat pesisir rata-rata kerja pada sektor laut dan hampir semua tinggal di tepi-tepi pantai. Kampung pesisir wilayah daratannya berbatasan dengan laut, sedangkan batas di laut ialah daerah-daerah yang juga digunakan untuk kegiatan-kegiatan masyarakat pesisir di daratan. Dari situlah yang menyebabkan lingkungan masyarakat pesisir tercemar, bau, dan kotor, sedangkan pada masyarakat kota lingkungannya sangat bersih karena masyarakat kota sangat menjaga dan melestarikan lingkungan yang bersih. Hal itu terjadi karena di kota ratarata yang tinggal adalah orang-orang kaya, bendoro, priyayi, dan mentri-mentri. 
Dalam aspek lingkungan masih belum pernah ada yang meneliti sebelumnya, karena ratarata penelitian terdahulu lebih fokus pada kesenjangan sosial dan ekonomi. Jadi dari aspek lingkungan yang ada pada penelitian ini belum ada yang meneliti mengenai kesenjangan lingkungan. Hal ini, karena dalam kesenjangan lingkungan terjadi antara masyarakat pesisir dengan perkotaan.

\section{Aspek Sosial}

Terjadi ketidaksetaraan antara masyarakat pesisir dengan perkotaan dalam aspek sosial. Hal itu terjadi karena garis kemiskinan yang berbeda. Perbedaan itu seperti nilai sosial, norma sosial, pola perilaku organisasi, interaksi sosial, kekuasaan dan wewenang, dan lain sebagainya. Dilihat dari interaksi sosial, pada masyarakat pesisir interaksi sesama masyarakat sangat terjaga, berbeda pada masyarakat kota yang interaksi sosial dipengaruhi oleh faktor ekonomi. Faktor tersebut menjadi salah satu elemen yang menjadi dasar dalam berintekasi dengan sesama masyarakat. Mereka harus memilih dan memilah terlebih dahulu serta tidak sembarangan berinteraksi dengan orang lain, terutama pada masyarakat miskin. Artinya, bahwa dalam kehidupan masyarakat pesisir interaksi sosialnya sangat kuat dengan masyarakat lain karena mempunyai pergaulan yang saling mengenal dan saling gotong royong.

Dalam kesenjangan sosial-ekonomi, terutama pada aspek sosial, penelitian sebelumnya yang dilakukan oleh Syahwi lebih banyak menjelaskan mengenai kesejangan ekonomi. Hal itu berbeda dengan penelitian ini, kesenjangan sosial tidak hanya terjadi pada kesenjangan ekonomi saja, tetapi juga mengenai nilai sosial, interaksi sosial, dan norma sosial yang sering terjadi dalam kehidupan manusia. Dalam hal itu, kesenjangan tidak lepas dari sosial maupun ekonomi, dua aspek tersebut saling berhubungan sehingga menyebabkan kesenjangan pada kehidupan manusia. Menurut Syahwi (2011) kesenjangan yang luas tidak hanya berakibat pada ekonomi, tetapi juga berdampak besar terhadap kondisi psikologi manusia. Maka dikatakan bahwa kesenjangan adalah kerawanan yang besar dan kesenjangan adalah ketidakmerataan akses terhadap sumber daya ekonomi. Masalah kesenjangan adalah masalah keadilan, yang berkaitan dengan masalah sosial (Syahwi, 2011). Dari pendapat di atas, bahwa kesenjangan sosial saling berkaitan dengan kesenjangan ekonomi, dimana dalam interaksi sosial pada masyarakat perkotaan selalu dipengaruhi oleh faktor ekonomi. Misalnya, masyarakat kota hanya ingin berinteraksi dengan orang-orang yang berkelas atau orang yang mempunyai derajat tinggi, mereka tidak mungkin berbicara dengan orang-orang pinggiran seperti masyarakat pesisir karena tidak sederajad dengannya.

\section{Aspek Budaya}

Pada masa kolonial, budaya yang sering terjadi adalah budaya perkawinan dan kekuasaan. Dalam masa itu, budaya perkawinan terjadi pada masyarakat pesisir dengan perkotaan. Budaya perkawinan terjadi karena adanya kekuasaan yang melekat begitu erat di tengah masyarakat kota. Para orang tua masyarakat pesisir yang mempunyai anak perempuan akan dijodohkan dengan Bendoro atau orang kota, semua itu terjadi karena faktor ekonomi. Masyarakat pesisir menjodohkan anaknya lantaran ekonominya yang kurang atau terbatas. Orang-orang kota sangat berkuasa dengan itu karena mereka merasa memiliki kekayaan yang melimpah, sehingga menikahi perempuan-perempuan pesisir sebagai kesenangan. Berbeda dengan masyarakat pesisir yang mengaggap menikah dengan orang kota lantaran desakan ekonomi.

Penelitian ini mempunyai kemiripan dengan penelitian sebelumnya dalam aspek budaya. Penelitian sebelumnya yang dilakukan oleh Sutopo membahas mengenai budaya lokal yaitu pelestarian batik pada masyarakat Pamekasan yang menyebabkan terjadinya kesenjangan sosial dari faktor struktural dan kultural. Selain faktor struktural dan kultural, yang 
menyebabkan kesenjangan sosial adalah patriarkis dan menempatkan perempuan di bawah lakilaki (Sutopo, 2013). Dalam faktor kultur yang dominan membuat perempuat tidak dapat mengakses pendidikan yang lebih tinggi, sehingga peluang mereka untuk menduduki struktur yang lebih tinggi juga tertutup, reproduksi sosial peran perempuan hanya terbatas sebagai buruh batik. Akibatnya pengusaha besar atau industri rumahan yang memiliki alat produksi mendapatkan keuntungan dari buruh batik tersebut, sehingga terjadi kesenjangan sosial pada perempuan. Hal itu mempunyai kemiripan yang terjadi pada kehidupan masyarakat pesisir, bahwa dalam kehidupannya memiliki budaya patriarkis. Dimana, seorang perempuan yang miskin dan bodoh selalu direndahkan. Hal tersebut terjadi karena faktor ekonomi yang menyebabkan kesenjangan pada kehidupan perempuan.

\section{SIMPULAN}

Dalam novel Gadis Pantai karya Pramoedya Ananta Toer menceritakan tentang representasi kesenjangan sosial-ekonomi antara masyarakat pesisir dengan perkotaan. Direpresentasikan dalam lima aspek, yaitu (1) aspek ekonomi, (2) aspek pendidikan, (3) aspek lingkungan, (4) aspek sosial, dan (5) aspek budaya. Dalam lima aspek tersebut, novel Gadis Pantai merupakan miniatur dari realitas yang terjadi di Indonesia pada kurun waktu 1965. Di dalam novel tersebut terjadi ketimpangan pembangunan pada lima sektor ini, karena pembangunan hanya berpusat pada pembagunan perkotaan saja, sedangkan pada daerah pesisir pembangun diabaikan sehingga menyebabkan tidak meratanya pembangunan pada kehidupan masyarakat pesisir. Hal tersebut, terjadi karena orientasi pembangunan yang dilakukan oleh pemerintah pada era tersebut yang hanya beroreintasi pada perkotaan sebagai pusat peradaban manusia. Representasi kesenjangan yang terjadi dalam kehidupan masyarakat pesisir dan perkotaan seperti dikotomi masyarakat pesisir yang miskin, bodoh, kotor, terhina dan orang bawahan, sedangkan masyarakat perkotaan direpresentasikan sebagai bangsawan, pintar, kaya, terhormat, bersih, dan orang atasan.

\section{DAFTAR PUSTAKA}

Ahmadi, A. (2010). Ilmu sosial dasar. Jakarta: PT Rineka Cipta.

Amanah, S. (2010). Peran Komunikasi Pembangunan dalam Pemberdayaan Masyarakat Pesisir. Jurnal Komunikasi Pembangunan, 8(1), 11-19.

Andalas, E. F. (2016). Citra Antikolonial dalam Film Avatar (2009): Sebuah Tinjauan Poskolonial Puitika Jurnal Humaniora, 12(1), 1-10.

Andalas, E. F. (2017). Eskapisme Realitas dalam Dualisme Dunia Alice Telaah PsikologiSastra Film Alice in Wonderland (2010). KEMBARA: Jurnal Keilmuan Bahasa, Sastra, dan Pengajarannya, 3(2), 185-195.

Aryadi, M. (2012). Hutan Rakyat: Fenomenologi Adaptasi Budaya Masyarakat. Malang UMM Press.

Astuti, R. D. (2016). Nilai Sosial dalam Novel Gadis Pantai Karya Pramoedya Anantatoer. Jurnal Pesona, 2(1), 1-7.

Daraba, D. (2015). Faktor-Faktor yang Mempengaruhi Keberhasilan Program Pemberdayaan Masyarakat Miskin di Kecamatan Polongbangkeng Utara Sosiohumaniora, 17(2), 165179.

Hakim, D. L. (2010). Aksesibilitas Air Bersih bagi Masyarakat di Pemukiman Linduk Kecamatan Pontang Kabupaten Serang. Version, 7(2), 127-136.

Hariyanto, A. (2014). Studi Pengembangan Ekonomi Lokal Terkait Interaksi Desa-Kota. Jurnal Perencanaan Wilayah dan Kota, 14(1), 1-14. 
Hidayat, M. T. (2018). Pengembangan Bahan Ajar Menulis Pantun Menggunakan Media Mencari Pasangan Kartu pada Siswa Kelas VII SMP Negeri 12 Langsa. Jurnal Samudra Bahasa, 1(2), 64-73.

Juhari. (2010). Reintrumentasi Fungsi Zakat Menuju Pengentasan Kesenjangan Sosial Ekonomi Umat. Al-Ihkam, 4(1), 114-126.

Meyrizki, S. Y., \& Pandjaitan, N. K. (2011). Representasi Sosial tentang Kota pada Komunitas Miskin di Perkotaan. Sodality, 5(2), 147-158.

Moleong, L. (2013). Metodologi Penelitian Kualitatif. Bandung: PT. Remaja Rosdakarya.

Nurhanifah, N. (2012). Representasi Unsur Religi dalam Novel Gadis Pantai Karya Pramoedya Ananta Toer (Sebuah Kajian Sosiologi Sastra dengan Penekanan Teori Sosiologi Agama Clifford Geertz). Students e-Journal, 1(1), 1-14.

Perwitasari, M. E., \& Hendariningrum, R. (2014). Analisis Wacana Kritis Feodalisme dan Diskriminasi Perempuan Jawa dalam Novel Gadis Pantai Karya Pramoedya Ananta Toer. Jurnal Ilmu Komunikasi, 7(3), 212-227.

Pinto, Z. (2015). Kajian Perilaku Masyarakat Pesisir yang Mengakibatkan Kerusakan Lingkungan (Studi Kasus di Pantai Kuwaru, Desa Poncosari, Kecamatan Srandakan, Kabupaten Bantul, Provinsi DIY). Jurnal Wilayah dan Lingkungan, 3(3), 163-174.

Rahman, P. L. (2012). Gambaran Pola Asuh Orang Tua pada Masyarakat Pesisir Pantai. Predicara, 1(1), 21-36.

Rosana, E. (2011). Modernisasi dan Perubahan Sosial. Jurnal Tapis, 7(1), 46-62.

Rusdina, A. (2015). Membumikan Etika Lingkungan bagi Upaya Membudayakan Pengelolaan Lingkungan yang Bertanggung Jawab. Jurnal Istek, 9(2), 244-263.

Setiawan, A. (2015). Anak Putus Sekolah pada Masyarakat Marginal di Perkotaan (Studi terhadap Masyarakat di Kelurahan Meranti Pandak Kecamatan Rumbai Pesisir Kota Pekanbaru). Jurnal Online Mahasiswa (JOM) Bidang Ilmu Sosial dan Ilmu Politik, 2(1), $1-15$.

Sutopo, O. R. (2013). Faktor Struktural dan Kultural Penyebab Kesenjangan Sosial: Kasus Industri Batik Pamekasan Madura. Komunikasi, 5(2), 230-239.

Syahwi, M. (2011). Kemiskinan dan Kesenjangan Sosial. Informasi, 16(3), 213-219.

Syahza, A., Bakce, D., \& Hamlin, N. (2015). Strategi Percepatan Pembangunan Ekonomi melalui Penataan Kelembagaan dan Industri Karet Alam di Propinsi Riau. Jurnal Online Mahasiswa (JOM) Bidang Pertanian, 2(1), 1-12.

Tamara, R. M. (2016). Peranan Lingkungan Sosial terhadap Pembentukan Sikap Peduli Lingkungan Peserta Didik di SMA Negeri Kabupaten Cianjur. Jurnal Geografi Gea, 16(1), 44-55.

Toer, P. A. (2006). Gadis Pantai. Jakarta: Lentera Dipantara.

Wanti, K. (2014). Representasi Kebudayaan Masyarakat Suku Lio dalam Novel Ata Mai. Jurnal NOSI, 2(7), 654-667.

Wibowo, P. N. H. (2015). Novel Gadis Pantai Karya Pramoedya Ananta Toer sebagai Dasar Penciptaan Skenario. REKAM: Jurnal Fotografi, Televisi, dan Animasi, 11(1), 53-68.

Yunus, R. (2013). Transformasi Nilai-Nilai Budaya Lokal sebagai Upaya Pembangunan Karakter Bangsa. Jurnal Penelitian Pendidikan, 13(1), 67-79. 